\title{
Mapping social values of ecosystem services: What is behind the map?
}

\author{
$\underline{\text { Laura Nahuelhual }}^{1,2,3}, \underline{\text { Felipe Benra Ochoa }}^{4}, \underline{\text { Fernanda Rojas }}^{5,6}$, G. Ignacio Díaz $^{7,8}$ and Alejandra Carmona $^{3}$
}

\begin{abstract}
A growing interest in mapping the social value of ecosystem services (ES) is not yet methodologically aligned with what is actually being mapped. We critically examine aspects of the social value mapping process that might influence map outcomes and limit their practical use in decision making. We rely on an empirical case of participatory mapping, for a single ES (recreation opportunities), which involves diverse stakeholders such as planners, researchers, and community representatives. Value elicitation relied on an individual open-ended interview and a mapping exercise. Interpretation of the narratives and GIS calculations of proximity, centrality, and dispersion helped in exploring the factors driving participants' answers. Narratives reveal diverse value types. Whereas planners highlighted utilitarian and aesthetic values, the answers from researchers revealed naturalistic values as well. In turn community representatives acknowledged symbolic values. When remitted to the map, these values were constrained to statements toward a much narrower set of features of the physical (e.g., volcanoes) and built landscape (e.g., roads). The results suggest that mapping, as an instrumental approach toward social valuation, may capture only a subset of relevant assigned values. This outcome is the interplay between participants' characteristics, including their acquaintance with the territory and their ability with maps, and the mapping procedure itself, including the proxies used to represent the ES and the value typology chosen, the elicitation question, the cartographic features displayed on the base map, and the spatial scale.
\end{abstract}

Key Words: cultural ecosystem services; recreation opportunities; social value mapping; southern Chile

\section{INTRODUCTION}

Spatial representation of ecosystem services (ES) is acknowledged as a key footstep for mainstreaming the ES framework into decision making (Hauck et al. 2013, Villamagna et al. 2013). In the last decade, a range of methods has been proposed for this endeavor (see Nelson et al. 2009 and Nahuelhual et al. 2015 for comprehensive reviews). The first category of methods involves the assessment of multiple ES, where a reduced number of economic value estimates are spatially transferred to other locations (Wong et al. 2015). A second category consists of modeling the provision of one or few ES at small scales using ecological production functions (Laterra et al. 2012) that relate ES flows with spatial variables that stand for ecological functions and processes. The third category consists of the use of landscape capacity matrices that relate land uses and covers to the provision of ES (Burkhard et al. 2009).

A fourth and most recent kind is the mapping of social values of ES, a mode of spatially explicit valuation, which stresses social perceptions, values, and priorities over economic and ecological indicators. It is a participatory approach that engages stakeholders, individually or in groups, through the use of different elicitation instruments such as online surveys (Sherrouse et al. 2014), open-ended interviews (Plieninger et al. 2013), and workshops (Palomo et al. 2014). Studies may rely on a previous classification of social values, to which participants are referred (Sherrouse et al. 2014). Or, participants are allowed to freely express values, which are afterwards linked to a bundle of ES by the researcher and spatially represented (Raymond et al. 2009). Map outcomes usually convey social values as measures of diversity, richness, abundance, and rarity (Bryan et al. 2010 , Palomo et al. 2014, Sherrouse et al. 2014).

Although valuation of ES using social value mapping has been supported by the academic sector as an approach to increase awareness of nature's benefits, to foster local empowerment, to effectively incorporate local knowledge in management decisions, and as a potentially more pluralistic and heterogeneous alternative toward value and valuation (Scholte et al. 2015), ecological and economic approaches and indicators still dominate ES research and policy (Kenter et al. 2015). A central reason for this comes from the disparate ways of conceptualizing, measuring, and mapping social values (Kenter et al. 2014). For example, several terms are used to refer to social values such as cultural (Darvill and Lindo 2015), shared (Kenter et al. 2015), socio-cultural (Sholte et al. 2015), and societal values (FelipeLucía et al. 2014). Furthermore, these terms are applied indistinctly in different contexts (Ives and Kendal 2014, Kenter et al. 2014), to refer to community norms, the public interest, the worth of public goods, values that people hold in social situations, contribution to well-being, and willingness to pay among others (Kenter et al. 2014, 2015).

For some disciplines contributing to the ES literature and social value assessment (sociology and psychology), the term value is used to describe the values of people, also referred to as underlying or held values. Held values can be classified as "desirable modes of conduct (e.g. honesty), end-states of existence (e.g. freedom), or qualities (e.g. beauty)" (Bengston 1994:232). In other disciplines (economics and geography), the concept of value lies

\footnotetext{
${ }^{1}$ Instituto de Economía Agraria, Universidad Austral de Chile, ${ }^{2}$ Centro FONDAP de Investigación en Dinámica de Ecosistemas Marinos de Altas Latitudes (IDEAL), ${ }^{3}$ Centro de Ciencia del Clima y la Resiliencia (CR2), ${ }^{4}$ Escuela de Ingeniería en conservación de Recursos Naturales, Facultad de Ciencias Forestales y Recursos Naturales, Universidad Austral de Chile, ${ }^{5}$ Instituto de Ciencias de la Tierra, Universidad Austral de Chile, ${ }^{6}$ Instituto de Ciencias Ambientales y Evolutivas, Universidad Austral de Chile, ${ }^{7}$ Doctorado en Ciencias Forestales, Escuela de Graduados Facultad de Ciencias Forestales y Recursos Naturales, Universidad Austral de Chile, ${ }^{8}$ Instituto de Conservación, Biodiversidad y Territorio, Universidad Austral de Chile.
} 
in the object realm and is concerned with the relative importance or worth of an object, often called the object's assigned value (Brown 1984, Bengston 1994).

Different typologies to classify ES social values have been proposed within the ES literature. Chan et al. (2012) distinguished eight binary and nonmutually exclusive dimensions of values, e.g., market mediated vs nonmarket mediated, self-oriented vs other-oriented. Brown (2013), proposed 14 types of place-based values, which the author described as an operative form of ES social values. Under this typology, social values of ES have been defined as "the perceived qualities carried by a natural environment that provide benefits to support human wellbeing" (van Riper et al. 2012:164). In Brown's typology, the names given to values coincide with the definition of ES such as the case of spiritual values, or with the description of benefits such as economic and therapeutic, a problem that Chan et al. (2012) named the conflation between ES, benefits, and values, a problem that has also been raised by other authors (Spangenberg et al. 2014). Kenter et al. (2015) identified seven nonmutually exclusive shared/social values, which were classified in transcendental, cultural and societal, communal, group, deliberated, other-regarding values, and value to society. In turn, Kellert (1995) proposed a human value typology based on the notion of the Biophilia hypothesis (Wilson 1984), which asserted a human dependence on nature that extends beyond material and physical sustenance to include aesthetic, intellectual, and spiritual meanings, and is the one used in this study.

Along with this conceptual diversity, social value assessments have used different methods of valuation (see Kenter et al. 2015 for a thorough revision) without considering the theoretical underpinnings (Ives and Kendal 2014, Raymond et al. 2014). Particularly, mapping of social values is a noneconomic instrumental approach (Raymond et al. 2014) that focuses on scoring, grading and spatially identifying social values.

In synthesis, social value mapping studies currently target a range of ES types, a diversity of value concepts, use different techniques, and declare different purposes for their endeavors. These purposes range from scientific inquiry, e.g., relation between land covers and social values, to private and public decision making, e.g., regulation and control of protected areas.

Recent contributions acknowledge that if social values of ES are to be considered in decision making, gaining conceptual and methodological clarity is essential for their application (Kenter et al. 2014, 2015, Gould et al. 2015). We aimed at contributing to such clarity by qualitatively exploring aspects of the social value mapping process that influence map outcomes and limit their practical use in decision making. We did so by critically analyzing the details of the implementation of a participatory nondeliberative mapping exercise for a single ES, namely recreation opportunities. We aimed at answering questions such as what types of social values are expressed and mapped by participants, what these values held for or assigned to, how much do the notion and spatial representation of social values differ across stakeholders, and what factors explain these differences.

We hypothesized that map outcomes (spatial social values of ES) are influenced by aspects of the methodological setting as well as aspects inherent to the stakeholders and the relationship between the two. Such aspects should be taken into consideration and uncovered if the resulting social value maps are to be of utility for decision making. This is particularly important in countries with developing economies where valuation of ES faces a myriad of methodological, practical, ontological, epistemological, and policy challenges (Christie et al. 2012). Although social valuation of ES can be highly context-specific, our results provide more general insights that contribute to the improvement of social value mapping assessments.

\section{METHODS}

This study was carried out in the municipality of Panguipulli, in the Los Ríos Region, southern Chile. Panguipulli municipality $\left(38^{\circ} 30^{\prime}-40^{\circ} 5^{\prime}\right.$ South, $71^{\circ} 35^{\prime}-72^{\circ} 35^{\prime}$ West) has an area of $3292 \mathrm{~km}^{2}$, and a total population of 33,273 people, of which $52.2 \%$ are considered rural and $25.3 \%$ are indigenous (INE 2002). According to the Chilean Native Vegetation Resource Cadaster (CONAF 2014), the main land cover is 154,200 ha of old-growth native forest $(42.38 \%$ of the total municipality area), followed by 59,400 ha $(16.32 \%)$ of secondary native forests, and 53,100 ha $(16 \%)$ of agricultural lands and pastures. Exotic-tree plantations constitute 7000 ha $(1.92 \%)$ and urban and industrial areas cover 712 ha $(0.19 \%$; Fig. 1$)$.

Panguipulli has outstanding natural features such as lakes, rivers, waterfalls, volcanoes, snow patches, pristine forests, and hot springs, all of which have granted the municipality a renowned reputation for tourism and made it a top tourist destination. In 2006, the municipality was formally declared a national tourist destination and it became part of the group of Areas of Touristic Interest (Ministerio de Economía, Fomento y Reconstrucción 2005, Ministerio de Economía, Fomento y Turismo 2012). Currently, Panguipulli is part of the Reserve of the Biosphere of the Temperate Rainforests of the southern Andes declared by the UNESCO in 2007 (CONAF 2007, Pino-Piderit et al. 2014). An important part of the municipality's total area is publicly protected by Villarrica National Park and Mocho Choshuenco National Reserve with 16,928 ha $(5.14 \%)$ and privately protected by six private conservation areas making up 48,515 ha $(14.7 \%)$. Despite rapid growth of tourism in the last years (near $16 \%$ between 2013 and the present), the main economic activities in the municipality continue to be cattle ranching, agriculture, and forestry (timber and firewood extraction from native forests and pulp from exotic-tree plantations; Municipalidad de Panguipulli 2008, 2012).

\section{Selection of stakeholders}

We defined a stakeholder following Freeman (1984) and Reed et al. (2009), as one who is affected by the decisions and actions taken by decision makers, and one who has the power to influence the outcome of such decisions. The identification of stakeholders relied on previously constructed actors' maps and power-interest matrices (Benra 2014, Tapia 2014), as well as our own knowledge of the study area and local representatives from different groups and institutions. Fourteen stakeholders were selected making up the following groups: seven planners from CONAF, the regional office of the National Tourism Service (SERNATUR), the municipality tourism office, the Regional Government of Los Ríos Region, and Panguipulli Model Forest; three researchers from the Center for Transdisciplinary Environmental Studies and 
Fig. 1. Study area in Panguipulli municipality, Los Ríos Region, Southern Chile.

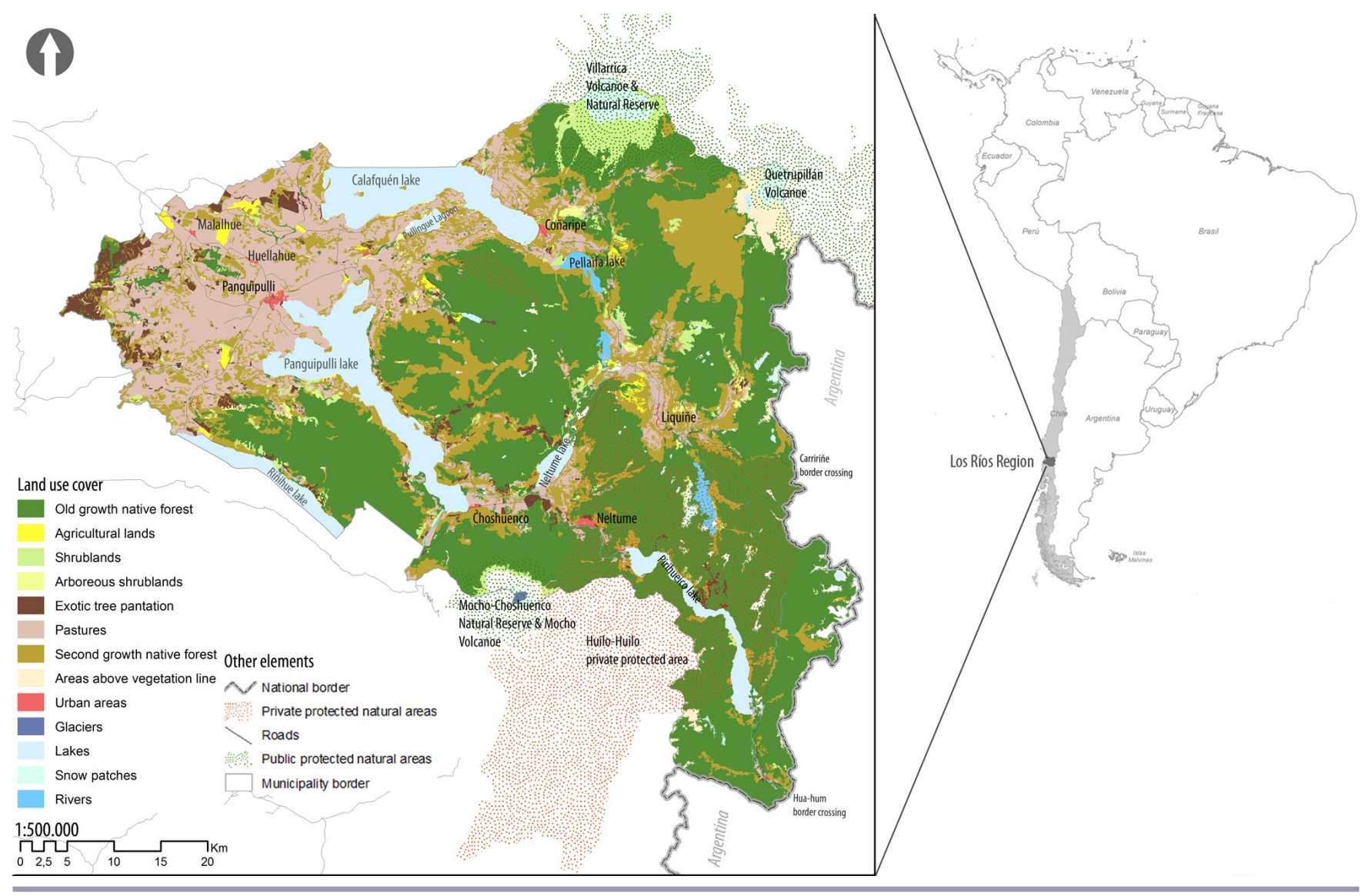

Sustainable Human Development (CEAM) of University Austral de Chile; four community representatives from the Panguipulli Environmental Coalition, the $\mathrm{Coz}-\mathrm{Coz}$ Indigenous Parliament, Puhuincul Community Tourism Association, and the Liquiñe's Association of Ecotourism and Guides.

Within the public institutions, CONAF's aim is for the sustainable management of forest ecosystems. SERNATUR is in charge of promoting tourist activities and infrastructure throughout the country. Regional governments are responsible for the administration of each of the country's regions, with the aim of fostering social, cultural, and economic development. Model Forests are public-private alliances that lead inclusive and participatory processes seeking sustainability goals (CATIERIABM 2012). In Chile, the Panguipulli Model Forest was implemented in 2005 with the goals of native forest management and conservation, promotion of local economic initiatives, and the implementation of mechanisms to foster associativity among stakeholders (http://imfn.net/es/bosque-modelo-panguipulli). CEAM is a research center that focuses on nature conservation and local development programs.

Among social representatives, the Parliament of $\mathrm{Coz}-\mathrm{Coz}$ is an indigenous organization whose mission it is to ensure the fulfillment of ancient rights of indigenous communities. Panguipulli's Environmentalist Coalition is a civil society organization that ensures sustainable development of the territory, as an agency reporting on the projects and actions that are undertaken in Panguipulli. The Community Tourism Association, Puhuincul, is a group of local inhabitants of the Mapuche ethnic group dedicated to small-scale tourism. Liquiñe's Association of Ecotourism and Guides is an organization dedicated to the implementation of local tourism, which emphasizes Mapuche culture and its relationship with nature. Representatives of the private sector, specifically owners of private protected areas and managers of ENDESA Electricity Company (Empresa Nacional de Electricidad S.A) were also contacted, but they did not answer the invitation.

\section{Ecosystem service selection}

We decided to evaluate a single cultural ES (recreation opportunities) instead of a bundle, to delve deeper and achieve a better understanding of the factors that might influence social valuation. To guide the exercise of mapping social values, two spatial proxies were chosen to represent recreation opportunities: natural capital and recreation activities (aquatic and terrestrial). These proxies were selected on the basis that a recreational opportunity is defined as a particular mixture of the natural setting (the physical landscape) and recreation activities that rely upon the physical as well as the built landscape, e.g., roads (MEA 2005, Chan et al. 2011). We used the following definitions, which were explained in simpler terms to the participants: recreational activities in natural environments were activities that depend on the ecosystem for their realization, and do not harm the 
environment; these activities were selected based on secondary data and the research team's knowledge and were grouped as activities carried out in the aquatic environment (e.g., kayaking, thermal waters, observation of flora and fauna) and activities carried out in the terrestrial environment (e.g., trekking, canopy rides in forests). Natural capital was defined as the stock of natural objects and relationships between these objects that are capable of producing a sustainable flow of biophysical resources that sustain both life and the human economy (Wackernagel and Rees 1997).

\section{Social value concept and typology}

We did not adopt a particular definition of social value, but we did focus on the distinction between held and assigned values. We expected both types of values to arise from the interviews. According to Brown (1984), values belong in three realms: the conceptual, the object, and the relational realm. Held values belong to the conceptual realm, where a value is defined as "an enduring conception of the good and is sometimes referred to as an ideal value" (Bengston 1994:520). Value in the object realm is concerned with the relative importance or worth of an object, often called the object's assigned value. In the relational realm, value arises from a connection between a subject and an object in a given particular context. In words of Bengston (1984:520), "The conceptual realm is concerned with an important part of the basis of value, the relational realm is concerned with the valuation process, and the object realm is concerned with the end result of the valuation process." Thus, by defining values in terms of one of the three realms, researchers focus on part of a broader valuation process (Bengston 1994).

Along with the distinction between held and assigned values, we selected a particular typology to interpret the values expressed by participants, specifically the typology of human values for nature proposed by Kellert (1995) (Table 1). As far as we know, this typology has not been used in the context of ES's social valuation, but it is largely similar to the structure of values proposed by other authors (Chan et al. 2012).

Table 1. Human values toward nature (Adapted from Kellert 1995).

\begin{tabular}{|c|c|}
\hline Value & Description \\
\hline Utilitarian & Value related to the material exploitation of nature \\
\hline Naturalistic & $\begin{array}{l}\text { Value related to a sense of fascination, wonder, and } \\
\text { admiration derived from the close experience of } \\
\text { nature }\end{array}$ \\
\hline Ecologistic- & Value related to the motivational need for precise \\
\hline Scientific & $\begin{array}{l}\text { study and systematic inquiry of nature (function and } \\
\text { structure) }\end{array}$ \\
\hline Aesthetic & $\begin{array}{l}\text { Value derived from the physical attractiveness and } \\
\text { beauty of nature }\end{array}$ \\
\hline Symbolic & $\begin{array}{l}\text { Value derived from the use of nature for language } \\
\text { and reflection }\end{array}$ \\
\hline Humanistic & $\begin{array}{l}\text { Value related to the emotional attachment and love } \\
\text { for nature }\end{array}$ \\
\hline Moralistic & $\begin{array}{l}\text { Value derived from the spiritual amazement and } \\
\text { ethical concern for nature }\end{array}$ \\
\hline
\end{tabular}

Interview design, testing, and application

The elicitation instrument combined an open-ended interview and a mapping exercise, and was based on the works of Raymond et al. (2009), Bryan et al. (2010), Hatton-MacDonald et al. (2013), and Palomo et al. (2014). In order to adjust the instrument and the elicitation procedure, a small workshop was held in May of 2014 with a total of six participants, who were researchers and students from Universidad Austral de Chile, engaged in research and development projects in Panguipulli. This workshop allowed for several modifications: a nondeliberative over a deliberative format was chosen; the quality of the map was improved (scale and resolution); recreational activities were included, along with natural capital, as spatial proxies of recreation opportunities; the number of marking possibilities was attuned; and the general handling of the mapping exercise was defined.

The final interview was conducted between June and August of 2014, and was registered using paper notes. It began by presenting the objectives of the research followed by the collection of personal information (e.g., gender, educational level, and ethnic background) and familiarity of participants with the territory. Some of the questions asked were the following: Do you acknowledge the administrative limits of the municipality? What proportion of the municipality are you familiar with? Have you carried out recreational activities in the municipality? After this first stage, the definitions of recreational activities and natural capital were given to the interviewees. Spatial representation of natural capital and recreational activities relied on a printed map of the municipality of 102.5 by $75.5 \mathrm{~cm}$ and of $1: 350,000$ scale, showing current land uses and covers (henceforth the base map; Fig. 2). The base map also displayed rivers, main road networks, urban areas, names of particular places, and landscape attributes such as lakes, rivers, and volcanoes.

For each interview, a sheet of tracing paper $(102.5 \times 75.5 \mathrm{~cm})$ was previously prepared delineated with rectangular cells of 2.2 by $2.3 \mathrm{~cm}$. Each cell accounted for a real area of $5.2^{2}$ kilometers. Thus, the tracing paper comprised a total of 720 cells distributed in 33 rows and 45 columns (Fig. 2). During the mapping exercise, this tracing paper was placed on top of the base map for participants to position marks using markers of different colors. This exercise was repeated for natural capital and recreational activities leading to two maps per person.

Based on previous studies (Bryan et al. 2010) and the pilot testing, a total of 60 possibilities of marks were allowed for natural capital and 40 for recreational activities. Only one mark was permitted in each cell of the tracing paper. Every participant was encouraged, but not obligated to assign all the given possibilities. Two valuation questions were asked to participants, leading to two different maps: "In which cells do you think there is value for natural capital?" and "In which cells do you think there is value for recreational activities?" These questions were intended to capture values based on the past and current experience of stakeholders with their territory as planners, scientists, or local inhabitants. Participants were allowed to express themselves freely about these questions and any other issues that could be of their interest. The interviewers used the participant observation technique, which is characterized by factors such as openmindedness, absence of prejudice, interest in learning more about others, and careful observation and listening (DeWalt and DeWalt 2010).

\section{Interview analysis}

Interviews provided information about the participants such as their experience in the territory and their relationship with it, 
Fig. 2. Mapping exercise showing the base map and tracing paper on which participants marked places of value of natural capital and recreational activities.

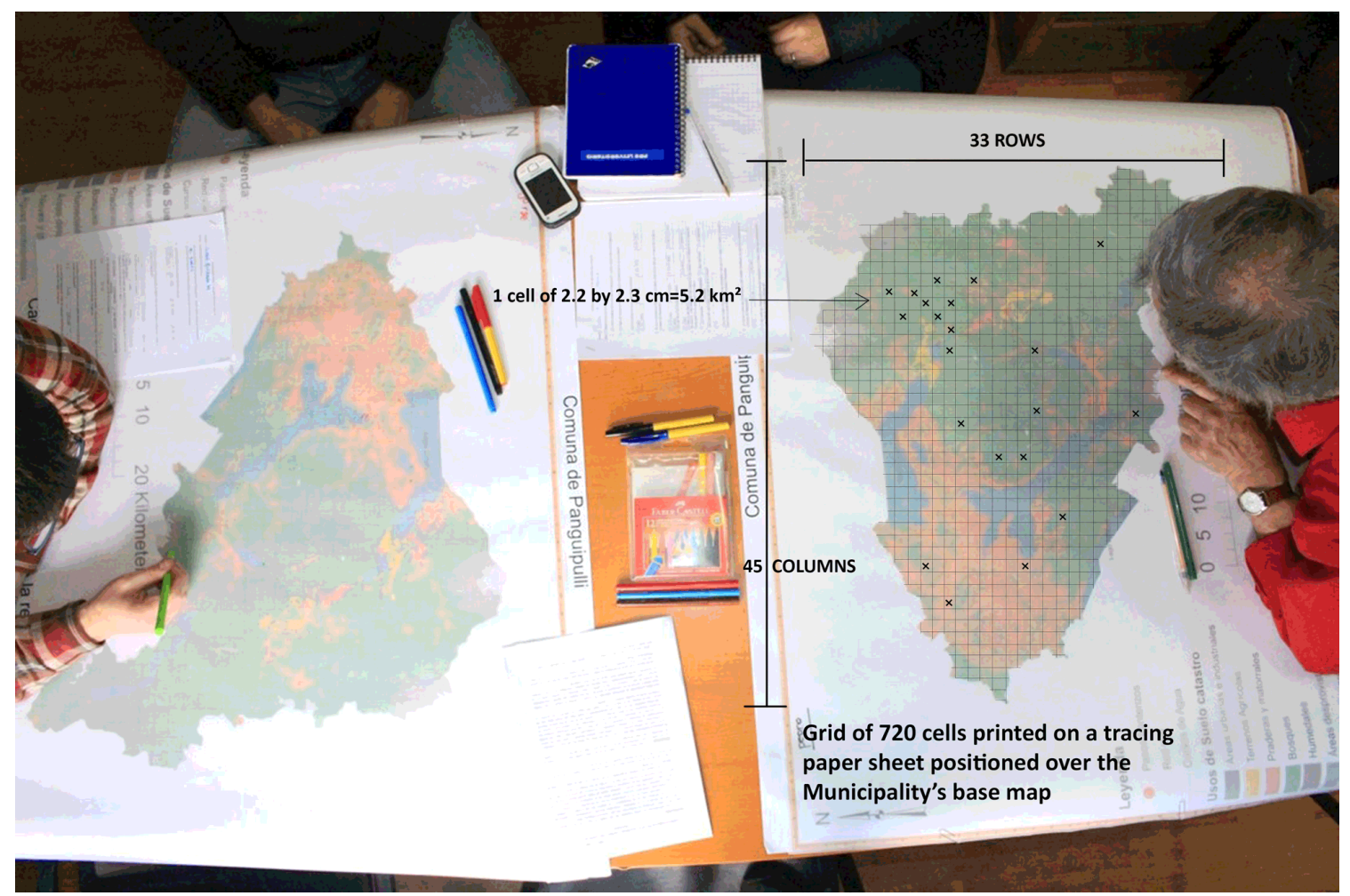

among other evidence. The most relevant details of the interviews emerged when the participants looked at the map. This was because the participants responded with personal stories, experience from institutions that they represented, and critical thinking about the objective of mapping natural capital and recreational activities in the territory. Because the interviews were not recorded, the qualitative analysis relied on the revision of the notes and on the interviewers' observations.

\section{Geographic Information System (GIS) analysis}

GIS analysis complemented the examination of the narratives and was aimed at exploring questions such as the following: "What are the values expressed by different stakeholders held for or assigned to and how much do these values differ across stakeholders?" Specifically the position of marks by the different groups (as indication of social values) was expected to be related to particular features of the physical and built landscape. These spatial outcomes, along with the narratives, allowed us to infer some response patterns and relate them to specific aspects of the participants or the methodology itself, e.g., expertise in using maps, map extent. Nonetheless, it is important to remark that exploring causality was beyond the purpose of the study.

First, a binomial database containing all the results for each participant was created and joined to the respective spatial grid from each of the three stakeholder groups (we uploaded an excel spreadsheet to the GIS program for each of the three stakeholder groups). Second, because the three groups had a different number of participants, we transformed (standardized) the data (0-1), so for each group we would have a minimum rate of 0 and a maximum rate of 1 . To visualize and analyze the data we created a raw grid map with standardized cell values. Each cell had a particular standardized value, that is, the ratio between the number of marks given to a particular cell and the sum of all marks given by all participants of every group. We then separated the cell values in four categories to better display the differences within and across groups.

A first GIS analysis was intended to explore whether or not there was a relationship between the positioning of marks for natural capital and recreational activities and particular elements of the physical (rivers, volcanoes, and lakes) and built landscape (road near settlements and settlements). This analysis relied on proximity rules detailed in Table 2 , and aimed at revealing the elements from the map that could act as attractors for mark placement, which in turn could be influenced by the features shown on the base map during the exercise.

In turn, to understand whether the spatial representation of social values (as reflected in the placement of marks) differed across stakeholders, we calculated measures of centrality and dispersion (Mean Weighted Center and Standard Deviational Ellipses, respectively). These measures served the purpose of identifying central tendencies and geographical dispersal of marks placed by each stakeholder group. The Mean Weighted Center of the marks was calculated to identify the center of gravity, considering individual weights in a set of points (Buzai and Baxendale 2006), which in this case were the aggregated number of marks placed 
on each cell by the participants. Standard Deviation Ellipses were generated for natural capital and recreational activities to measure the trend of the marks. The calculation of the standard distance separately in the $\mathrm{x}$ and $\mathrm{y}$ directions is a common way of measuring the trend for a set of points or areas. These two measures define the axes of an ellipse encompassing the distribution of features. The ellipse is denoted as the standard deviational ellipse, because the technique calculates the standard deviation of the $\mathrm{x}$ co-ordinates and $\mathrm{y}$ co-ordinates from the mean center to define the axes of the ellipse (Mitchell 2005). Both procedures were conducted in ArcGis 9.3 (Spatial Statistics Tools module).

Table 2. Proximity rules defined to identify attributes that influenced the positioning of marks for natural capital and recreation activities.

\begin{tabular}{ll}
\hline \hline Attribute & Description of the rule \\
\hline Volcanoes & $\begin{array}{l}\text { Cells within a buffer radius of } 10 \mathrm{~km} \text { from the } \\
\text { volcano summit }\end{array}$ \\
Lakes & Cells intersecting water bodies \\
Rivers & Cells intersecting river lines \\
Roads & Cells intersecting road lines \\
Settlements (cities, & Cells within a buffer radius of $3.16 \mathrm{~km}$ from the \\
towns, and villages) & urban settlement centroid. \\
\hline
\end{tabular}

\section{RESULTS}

Stakeholder characteristics and values

From the narratives, different types of values emerged, associated to participants' relationships with the territory (planners, scientists, or local representatives) and their degree of familiarity with it (Table 3). Planners were all men and had completed university education. Three out of seven resided in the municipality. All had a large involvement in tourism and forest planning at different administrative scales, and were well acquainted with the entire municipality area. The majority had participated in the creation of policies, plans, and programs oriented toward positioning Panguipulli as an important national and international tourist destination. Their professional training considerably facilitated the mapping exercise. When placing their marks on the map, a professional perspective predominated, although all of them recalled particular recreational experiences in the territory. In the case of natural capital, they distinguished those landscape features that are acknowledged by the tourism authority as icons for the expansion of tourism in the region, e.g., Panguipulli Lake, scenic points. In the case of recreational activities, they associated their marks to places where recreational activities have already been prioritized, e.g., aquatic recreational activities, within planning instruments such as the Tourism Development Plan and the Regional Territorial Plan. To a large extent, their opinions reflected the object realm of social values. Such assigned values predominantly reproduced utilitarian values, i.e., practical and material exploitation of nature, that could also be deemed as market-driven and other-oriented, rather than self-oriented values. Planners also expressed aesthetic values, i.e., physical appeal and beauty of nature, from their personal experience as visitors and recreationists in the territory, in which case values could be deemed as individual and self-regarded.
Table 3. Values inferred from the narratives of stakeholders during the interview and mapping exercise.

\begin{tabular}{lccc}
\hline \hline Value type & Planners & Scientists & $\begin{array}{c}\text { Local } \\
\text { representatives }\end{array}$ \\
\hline Utilitarian & $\bullet$ & $\bullet$ & $\bullet$ \\
Naturalistic & & $\bullet$ & $\bullet$ \\
Ecologistic- & $\bullet$ & $\bullet$ & \\
Scientific & $\bullet$ & & $\bullet$ \\
Aesthetic & & $\bullet$ & $\bullet$ \\
Symbolic & & & $\bullet$ \\
Humanistic & $\bullet$ &
\end{tabular}

Researchers were involved in development programs linked to local tourism initiatives, yet their acquaintance of the territory was less than that of the planners. None of them resided in the municipality and like planners, they had a high training in participatory cartography and held university degrees. Although familiar with the concept of ES, they had not incorporated the approach in their work, advocating for a biological conservation perspective. Regarding natural capital, they highlighted areas that were reportedly relevant for their own ventures, such as the buffer zone of the Reserve of the Biosphere of the Temperate Rainforests, Villarrica National Park, and the rural communities where they assist local tourism initiatives. Assigned values predominated over held values in their narratives. These values could be judged as utilitarian, prioritizing places with strategic features, comparable to the group of planners. Their narratives could also be related to ecologistic and scientific values (i.e., systematic study of structure, function, systematic inquiry of the natural world) as well as naturalistic (i.e., direct experience and exploration of nature), as they held a large commitment to nature conservation. Their values were also regarded as other-oriented and group values.

Community representatives had lived and worked in the territory their entire or most of their lives. Nonetheless, they were less acquainted with the municipality space than planners and researchers. They belonged to, or had a close attachment to the Mapuche indigenous peoples. Unlike planners and researchers, they had very limited experience with mapping, and less familiarity and acceptance of the concept of ES. Their reflections revealed a larger variety of assigned and held values, which were nonetheless much more related to their own idea of nature than to the concepts of natural capital and recreational activities. They expressed symbolic (i.e. use of nature for language and thought) as well as naturalistic values, that were reflected in statements such as, "there are places in my community that do not only hold recreational importance, but they also hold profound meaning, such as the "Ngen"." In the Mapuche group, the religious concept of "Ngen" is used to signify the spirits, owners of nature.

Table 3 summarizes those values that could be inferred from the narratives of participants. Nonetheless, these values corresponded to announcements during the interviews, but are not necessarily those reflected in the final map, where certain elements, particularly those that are symbolic, could not be spatially located. 
Fig. 3. Elements of the natural and built environment influencing the placement of marks by the different groups of stakeholders (colored lines). The scale ranges from 0 to 100 according to the percentage of cells that fell within each rule, described in Table 2 .

A

Natural Capital

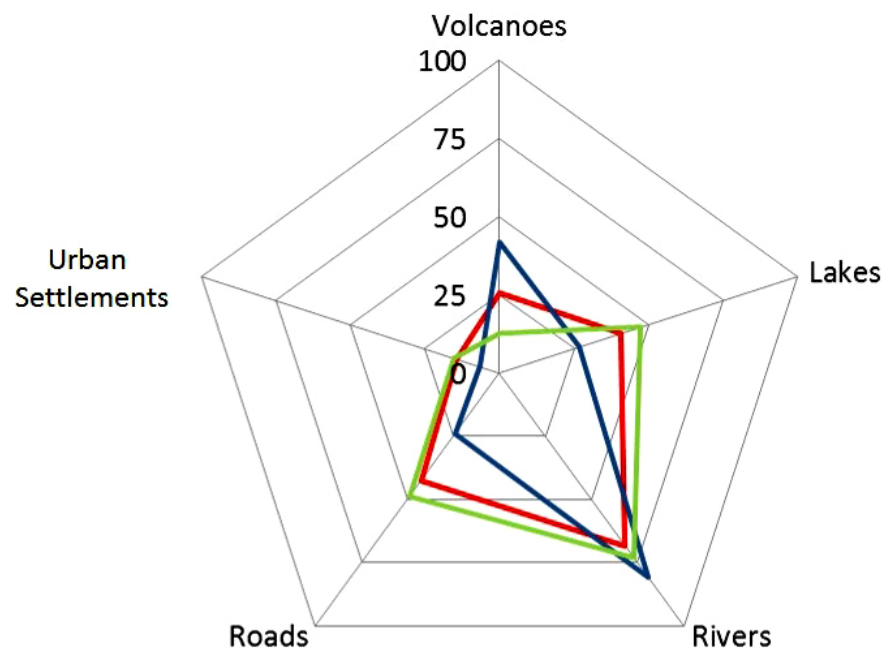

Recreational Activities

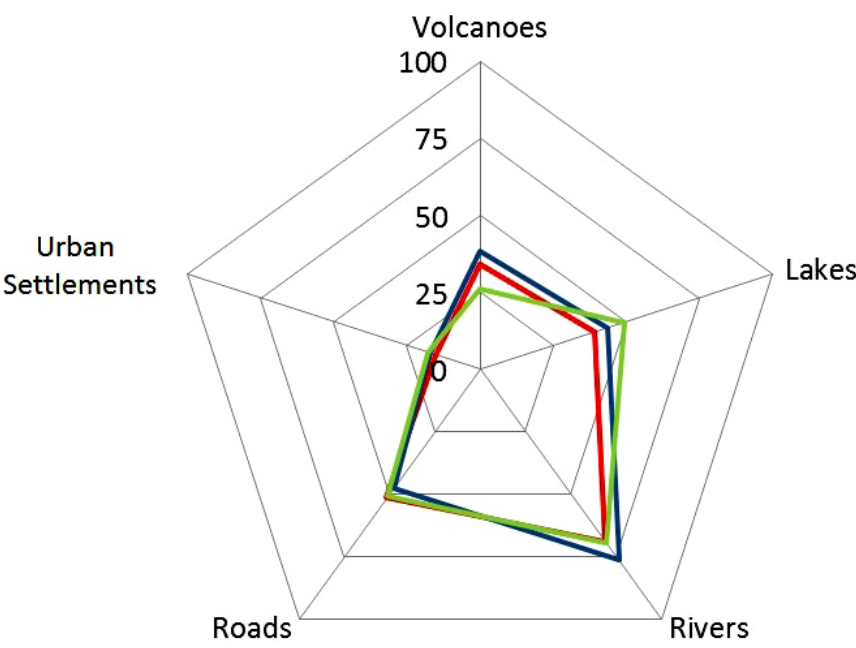

\section{Relation between mapping outcomes and landscape features}

Figure 3 shows the relation between the positioning of marks for natural capital (panel A) and recreational activities (panel B), to particular attributes of the physical (rivers, volcanoes, and lakes) and built landscape (roads near settlements and settlements). This gives insight about the attributes of the base map that drove personal decisions regarding the placement of marks and therefore social values.

Regarding the relationship between natural capital and landscape attributes (Fig. 3A), 34.1\% of marks placed by researchers were within a $10 \mathrm{~km}$ radius from volcano summits (Villarrica and Mocho-Choshuenco). This was consistent with the areas where their work territory was located; whereas for planners and community representatives, these numbers decreased to $25.4 \%$ and $12.7 \%$, respectively. In turn, 39\% of planners' marks intersected a river, a percentage that increased to $55 \%$ and $66 \%$ for community representatives and researchers, correspondingly. Lastly, $47 \%$ of marks placed by community representatives intersected a lake, as compared to $41 \%$ in the case of planners and $27 \%$ in the case of researchers. The placement of marks was also related to the presence of built attributes of the landscape (Fig. 3A). The results indicated that $52 \%$ and $51 \%$ of the marks of planners and community representatives, respectively, fell on cells that intersected roads. It was no coincidence that planners' marks concentrated along the circuit that encloses the main lakes of the municipality, being a local icon for tourism development. In turn, only $14 \%$ and $15 \%$ of their marks, respectively, fell within a $3.2 \mathrm{~km}$ buffer of urban settlements. In the case of researchers, only $24 \%$ of their marks were placed on cells intersecting roads, and only $7 \%$ were placed within the established settlement's buffer zone.
Regarding the relationship between recreational activities and physical landscape attributes (Fig. 3B), the three groups exhibited homogeneous patterns. The most noticeable differences occurred in the group of researchers, whose marks showed a relatively higher concentration around volcanoes and rivers (38\% and 77\% of marks, respectively), whereas community representatives concentrated the least amount of marks near volcanoes $(26 \%)$. Concerning built attributes (settlements $3.2 \mathrm{~km}$ buffer and intersection with roads), the three groups exhibited very similar concentrations of marks with $17 \%, 18 \%$, and $15 \%$ for planners, community representatives and researchers, respectively.

In synthesis, two tendencies were revealed: (i) irrespective of the stakeholder group and the proxy used, there was a close relation between the placement of marks and the presence of rivers and roads; (ii) there was a higher dispersion of marks in the case of natural capital as compared to recreational activities, irrespective of the stakeholder group. The case of rivers could be merely coincidental, given the large amount of rivers in the municipality and considering that they were not highlighted in the interviews.

\section{Map outcomes across stakeholder groups}

Figure 4 (A and B) shows the spatial distribution of marks that represent participants' social values for recreation opportunities, across groups of stakeholders. In the case of natural capital, mean weighted centers between planners and researchers were $9.8 \mathrm{~km}$ apart, whereas the mean center of the marks of community representatives lay in between both, and closer to that of planners. In turn, for recreational activities, the mean centers of the marks of planners and researchers were placed $7.7 \mathrm{~km}$ apart, with the center of community representatives being closer to researchers in this case. For natural capital, researchers positioned their marks closer to volcanoes and natural protected areas, whereas 
Fig. 4. Maps of central tendencies (panels A and B) and distribution of social values for recreation opportunities, obtained from the spatial analysis of the marks assigned by the three stakeholder's groups to natural capital (panels C, E, G) and recreational activities (panels D, F, H).

\section{Legend}

Mean weighted center

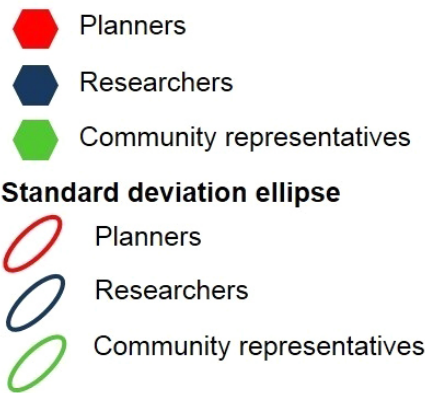

Attributes of the physical and built landscape Volcanoes and snow patches

Lakes

Urban settlements
Rivers
Roads

Number of marks (Standardized values)

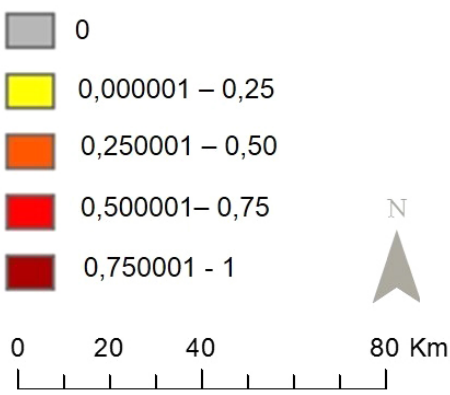

\section{NATURAL CAPITAL}
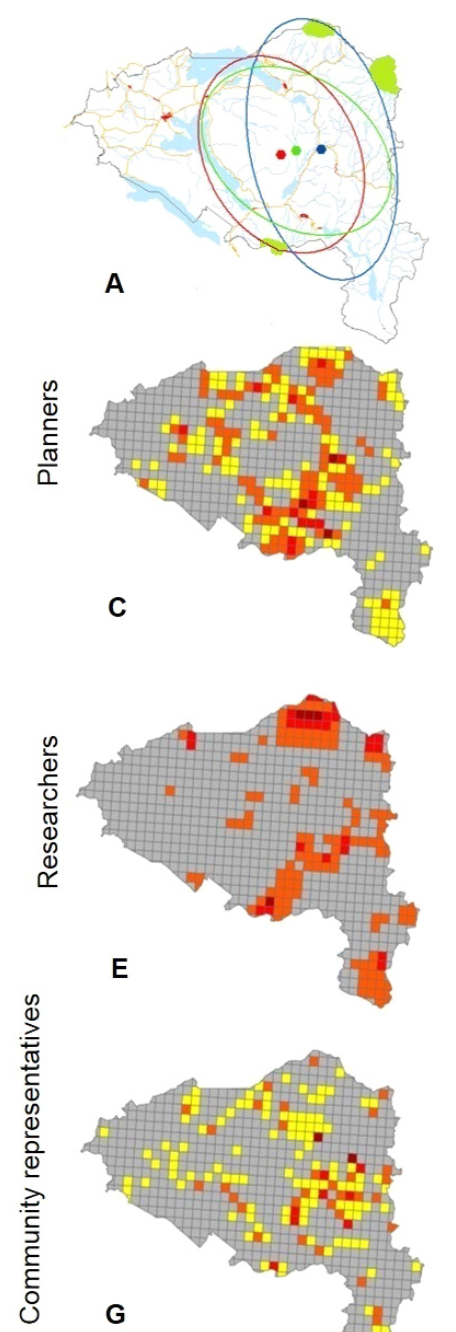

\section{RECREATIONAL ACTIVITIES}
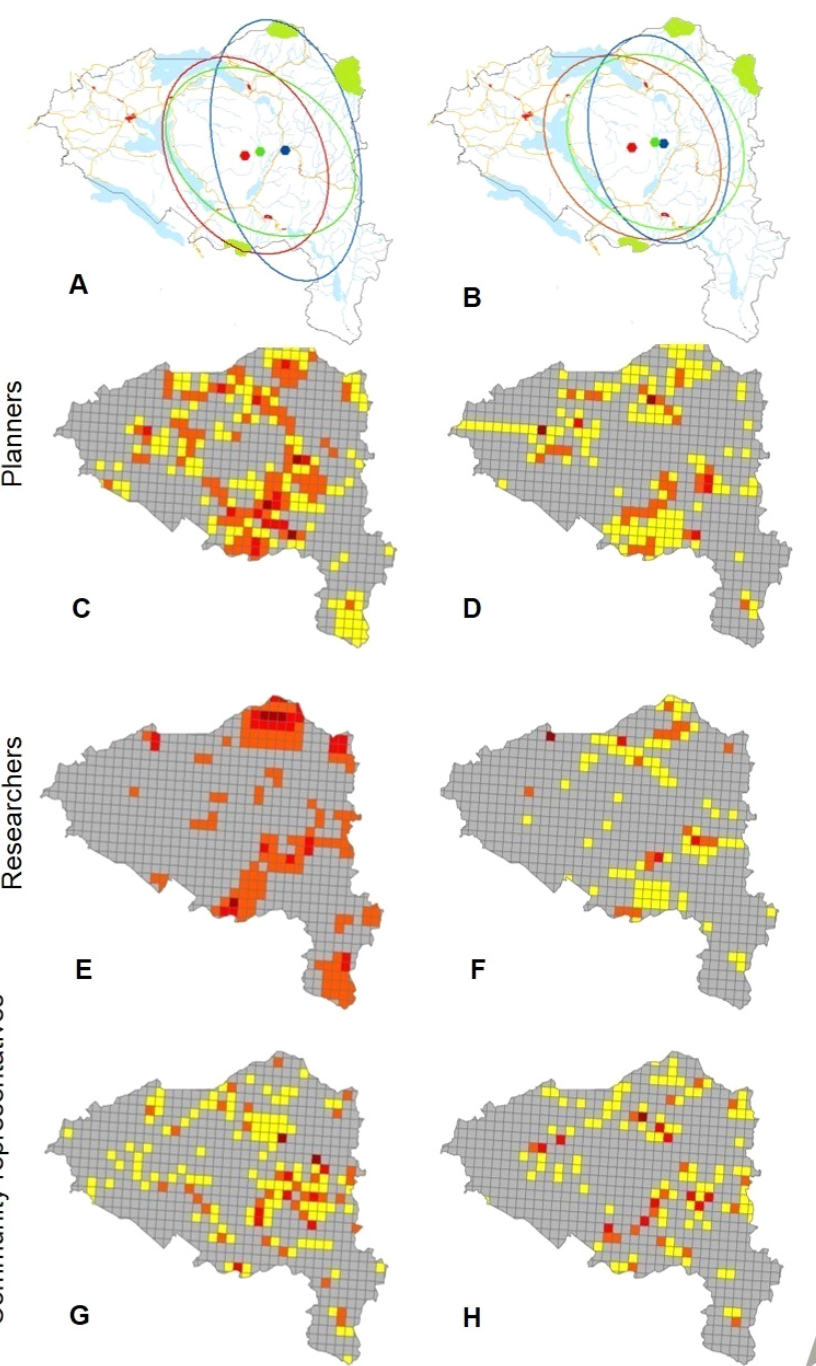

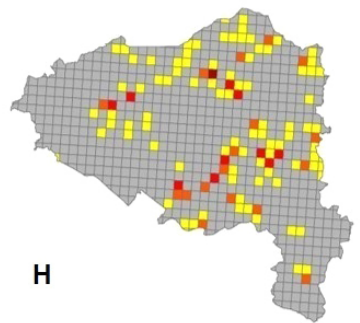

community representatives placed their marks on piedmont areas and valleys between Panguipulli and Calafquén lakes (see Fig. 1). For recreational activities, dispersion showed similar patterns for the three groups of stakeholders, with most marks concentrated on common places. In all cases, the east half of the municipality concentrated the highest amount of marks, which coincided with the location of native forest ecosystems and lakes, as opposed to the west part of the municipality, covered by agricultural lands and pastures.

The marks attached to natural capital by planners (Fig. 4C) concentrated around the northern edge of Panguipulli Lake, the Mocho-Choshuenco Natural Reserve, and the surroundings of Calafquén Lake, which was similar to the outcome of community representatives (Fig. 4G). In the case of researchers, almost the totality of marks clustered on natural reserves around volcanoes and in the specific area of Liquiñe-Neltume-Choshuenco because of its natural capital and ongoing recreational activities (Fig. 4E and F). It is important to notice that the three researchers largely coincided in the placement of their marks as indicated by the red color, particularly for natural capital. Instead, local representatives showed the largest differences as indicated by the significant number of yellow cells, for both natural capital and recreational activities.

A synthesis of factors influencing map outcomes

Figure 5 depicts three fundamental aspects that emerged from our case study and that may be related to map outcomes, although no causal relationships were explored: (1) stakeholder personal characteristics and background; (2) valuation setting or the way in which the valuation exercise was framed; and (3) the model, which was the spatial representation of the system to which social 
values were attached. The interaction of these factors made up the differing and unique characteristics of resulting narratives and maps (Table 3, Figs. 3 and 4).

Fig. 5. Interrelated factors that influence the outcomes from mapping of social value of ecosystem services.

\section{Resulting narratives} and social value maps
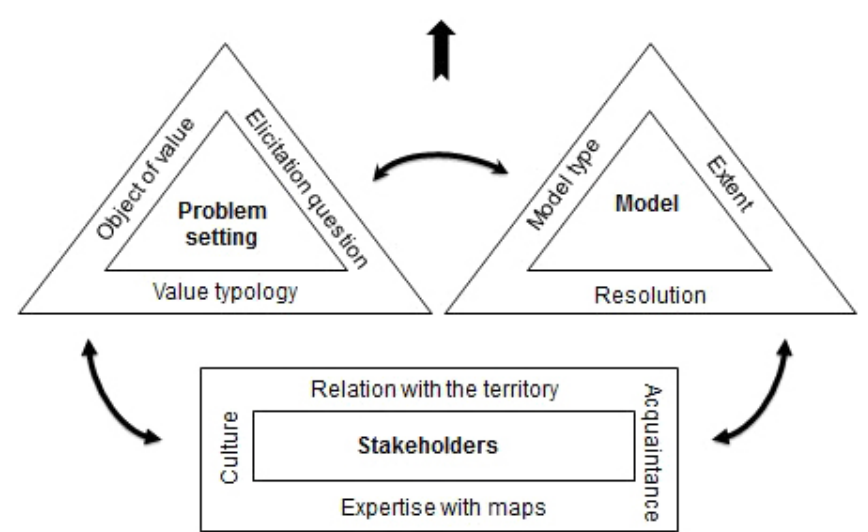

Regarding stakeholder personal characteristics and background, four interconnected aspects perceivably influenced map outcomes: (i) relation with the territorial space; (ii) acquaintance with the territory; (iii) expertise in using maps; and (iv) culture, understood as shared knowledge, values, and practices of local representatives that belonged to the Mapuche group. Stakeholder relationship and involvement with his/her territory as planner, researcher, or inhabitant, implied different value expressions and map displays (Table 3; Fig. 4) the same as the degree of acquaintance with the territorial space, with planners being the most knowledgeable in our case. In the case of local representatives, the interaction between acquaintance and the spatial extent of the base map led to marks being placed in areas where no particular landscape attributes were located (see Fig. $4 \mathrm{G}$ and $4 \mathrm{H})$.

Lower expertise with maps by community representatives led to situations such as the impracticality to locate places that they knew were of importance to them, e.g., special forest patches or family recreational sites, and placement of marks constrained around familiar attributes showed on the base map, regardless of their relation to natural capital or recreational activities, e.g., places around their hometowns. The results also showed differences in the values that emerged from the narratives of community representatives that belonged to indigenous groups. Symbolic values pertained indeed to the realm of the Mapuche people and related to physical objects, e.g., a mountain, and metaphysical representations, e.g. a spirit. These held and assigned symbolic and naturalistic values coexisted with a recognition of the importance of the utilitarian use of the landscape for their local livelihoods, e.g., local tourism initiatives such as horse riding and other amenities.

Valuation setting included the following: (i) the presentation to the participant of what was to be valued and mapped (the object of value), which in this case was the ES as represented by two proxies (natural capital and recreational activities); (ii) the wording of the elicitation question; and (iii) the value typology that we relied upon to interpret the values obtained. The narratives and the resulting maps showed evidence that the proxy used to represent the ES to be valued was not neutral, which was revealed by the differences between maps of natural capital and recreational activities (Fig. 4). Regarding the wording of the valuation question, it was not surprising that the notion of natural capital evoked more meanings than the concept of recreational activities, and the two concepts were associated to different landscape attributes by each stakeholder group (Fig. 3).

Value expressions were interpreted using a particular typology. According to this classification, several value types could be inferred from the narratives, e.g., utilitarian, symbolic, naturalistic. However, the mapping exercise bounded values to be assigned to particular attributes of the physical landscape, e.g., lakes in the case of community representatives, or places, e.g., buffer zones in the case of researchers (Fig. 3). In most cases, participants referred to places where they knew visitors could enjoy recreational activities in general, rather than places where they had experienced such activities. Furthermore, the identification of these attributes and places was clearly related to the features displayed on the base map.

The model comprised the extent and resolution of the base map (Fig. 5) as well as the representation itself. These three aspects posed clear difficulties for the participants, particularly local inhabitants. Beyond their skill in using maps or interest in the mapping exercise, all stakeholders manifested some degree of struggle with the base map, because it was hard to orientate themselves or it was impossible to be familiar with the entire area of the municipality $\left(3292 \mathrm{~km}^{2}\right)$.

\section{DISCUSSION}

Our results corroborate previous findings (Villamor et al. 2014, Davies et al. 2015, Scholte et al. 2015), that outcomes from mapping of ES' social values reflect the interaction of a series of factors related to the mapping exercise itself and to the participants. At least to some degree, the results may be an artifact of the mapping process itself (Cacciapaglia et al. 2012), which in this case involved the series of variables depicted in Figure 5. These aspects have not been well addressed in ES literature and their influence remains hidden in social mapping exercises, particularly in deliberative contexts where power and influence relations are not foreknown by the researcher and may influence map outcomes.

Other authors have described links between ES prioritized, values, and stakeholders' livelihoods (Maass et al. 2005, López-Santiago et al. 2014); and among policy and scientific knowledge and ES values (Villamor et al. 2014). In our case study, stakeholder background (Fig. 5) influenced map outcomes in ways that could have led to erroneous conclusions, such as that an area or landscape feature apparently holds little or no value (see Fig. 4). In reality, marks are not located in these places because of the lack of knowledge about those areas, as long as livelihoods are constrained to smaller territorial boundaries. Additionally, mapping exercises such as ours assume that people can use maps and scale categories, which requires a certain level of expertise, an assumption that did not necessarily hold in the case of local 
representatives. Therefore, given the importance of stakeholder representativeness in social value assessment and mapping (Fagerholm et al. 2012, Davies et al. 2015), mapping procedures should be adequately adapted to stakeholders' capacities by limiting technical difficulties, e.g., expertise with maps. The important issue of culture and valuation of ES has been discussed in recent papers (Klain and Chan 2012, Schnegg et al. 2014). Schnegg et al. (2014) concluded that whether or not local inhabitants' valuations converge with those from other social groups such as planners and scientists, remains an empirical question and that resolving potential differences among their views is likely to be a political, scientific, and epistemological challenge. In our present study, participants from the Mapuche culture stated values that clearly differed from those of the other two groups (Table 3, Fig. 4). It may also be the case that their relationship with nature does not conform to the concept of ES, an issue that was explicitly raised by one representative of the Coz-Coz Parliament. In this regard, researchers need to recognize that the ES approach entitles a specific ontology that frames the world in a particular way (Kull et al. 2015), in which certain values simply do not fit naturally (Chan et al. 2012). Stakeholders' culture (shared knowledge, values, and practices), which in this case alludes to the Mapuche people, can enable or impede the application of the ES framework in general, as well as social value mapping in particular. In these cases, forcing values onto a map may risk map validity and credibility.

Like in other approaches to ES valuation, e.g., economic valuation, the setting can influence map outcomes. In this case, the elicitation question asked participants to identify those places where they thought there was value for natural capital and recreational activities. The valuation question chosen in this work coincided with other studies such as Sherrouse et al. (2011), in which people were asked questions such as "In what ways do you value (a particular territorial space)?" and "To what places can you attribute such values?" based on a predefined typology of 12 values (Clement and Cheng 2006). This type of wording naturally constrained participants to express preferences toward geographic features, or to identify locations on the map where certain recreational values could be found, held, or experienced. However, whether ecosystems, ES, places, landscapes, or nature are homologous terms when it comes to eliciting social values remains an empirical question. Finally, the value typology encloses the discussion of the resulting values. If we had selected a different typology, we would have discussed another set of social values, such as intrinsic, biocentric, and transcendental values like in Chan et al. (2012). The typology chosen in this study (Kellert 1995) implicitly assumes that human values toward nature are anthropocentric (they are held or assigned by a human person), which might be in opposition to other social value typologies that try to emphasize the differences between self-regarded anthropocentric values and biocentric and other-regarded values, for example (Chan et al. 2012).

Stakeholder characteristics and valuation setting interacted with features of the base map in producing the final map outcomes. The two-dimensional paper representation of the study area was probably too simplistic in that it reduced the individual character of landscape perception into an overly narrow set of objects, e. g., lakes, rivers, volcanoes, roads. It also posed noticeable difficulties of scale, particularly for local representatives. Three- dimensional computer or paper representations might be much better options to deal with spatial resolution and extent. It is therefore important to previously test the model format, resolution, and extent, to elucidate which options stakeholders are more comfortable with. The latter practice has been scarcely undertaken in participatory mapping of ES. However two issues are yet to be addressed. First, the fact that by changing scales, researchers can affect map outcomes when providing a model onto which certain values and views fit or do not fit. In consequence, such maps reflect both the researcher's expectations of what is important, as well as the participant's views to the extent that they fit on the map (Cacciapaglia et al. 2012). Second, there is the notion that certain values simply cannot be mapped. Hall et al. (2009) acknowledged that many human values do not necessarily have a spatial dimension because they are intangible or nonmaterial. This occurred with the more symbolic representations of value depicted by Mapuche local representatives, especially those that alluded to territorial spirits of protection (the "Ngen") and naturalistic values.

To become an operational tool for decision making and empowerment, ES social value maps need to meet the criteria of credibility (scientific suitability of the technical evidence), salience (relevance of the assessment to decision makers' needs), and legitimacy (construction of information respecting stakeholders' diverging values and beliefs and in an unbiased way; Hauck et al. 2013). Improving social value mapping to meet these criteria and to mainstream it in territorial planning, calls for a process perspective, in which qualitative and quantitative mapping methods should be combined, rather than a single intervention like the one followed here and in most studies of this kind. By joining the instrumental approach toward social valuation with ethnographic and phenomenological approaches for example, researchers can "get a sense of what mechanisms people use, how and why they express, negotiate and justify their values and establish different meanings and understand the personal, political, societal processes whereby values are experienced, used, sensed, represented, formulated to constitute the individuals' being in the various everyday realms" (Tsirogianni and Gaskell 2011:460).

\section{CONCLUSIONS}

Combining participatory mapping methods and GIS for the assessment of spatial social values of ES requires a clear assessment of their respective strengths and weaknesses for different applications. In spite of this awareness, there has been little critical analysis evaluating the usefulness of current procedures. In most studies, the aim has been to represent the spatial distribution and concentration of social values of ES, without placing greater attention on the type of values reproduced in the maps by different individuals or on how peoples' specific characteristics interact with researchers' methodological decisions to produce a specific spatial representation. Our present study posed the question of what is behind the map, and aimed at exploring aspects of a social value mapping implementation that might influence map outcomes and limit their practical use in decision making. We conclude that the instrumental approach to social valuation of ES may only capture a subset of relevant values, which are derived from a myriad of opinions constructed around the objective, subjective, and/or personal interest of each individual. With final map outcomes being dependent on the participants, it is almost certain that including different and eventually more stakeholders, would produce different maps. 
Although narratives reflected assigned and held values, their distinction in the maps was not attainable with the methodological approach used here. Given the valuation setting and the model we used, which is the usual frame of the mapping exercises reported in other studies, individuals were restricted to map assigned values to objects of the landscape that were mostly those displayed on the base map. A relevant interaction influencing map outcomes was that between stakeholder's relation and acquaintance with their territory and the scale of the base map (extent and resolution).

Strengthening map validity requires the acknowledgement of what factors and in what manner they influence social mapping procedures. It also requires our effort in moving toward conceptual agreement regarding definitions of social values of ES and typologies to interpret those values, and unified implementations for assessing spatial social values.

Responses to this article can be read online at: http://www.ecologyandsociety.org/issues/responses. $\mathrm{php} / 8676$

\section{Acknowledgments:}

This research was funded by FONDECYT Grant $N^{\circ} 1151187$ (CONICYT-Chile), Grant from the Inter-American Institute for Global Change Research (IAI) CRN3095, which is supported by the US National Science Foundation (Grant GEO-1128040), and VESPLAN (CYTED Network 413RT0472). The authors wish to thank all the participants in this study and specially Panguipulli Model Forest representatives.

\section{LITERATURE CITED}

Bengston, D. N. 1994. Changing forest values and ecosystem management. Society \& Natural Resources 7:515-533. http://dx. doi.org/10.1080/08941929409380885

Benra, F. 2014. Mapeo del valor social del servicio ecosistémico oportunidades de recreación: Un caso de estudio en la comuna de Panguipulli, Región de los Ríos, Chile. Tesis Ingeniero en Conservación de Recursos Naturales. Valdivia, Chile. Facultad de Ciencias Forestales y Recursos Naturales, Universidad Austral de Chile.

Brown, G. 2013. The relationship between social values for ecosystem services and global land cover: an empirical analysis. Ecosystem Services 5:58-68. http://doi.org/10.1016/j. ecoser.2013.06.004 http://dx.doi.org/10.1016/j.ecoser.2013.06.004

Brown, T. C. 1984. The concept of value in resource allocation. Land Economics 60:231-246. http://dx.doi.org/10.2307/3146184

Bryan, B. A., C. M. Raymond, N. D. Crossman, and D. HattonMacDonald. 2010. Targeting the management of ecosystem services based on social values: where, what, and how? Landscape and Urban Planning 97:111-122. http://dx.doi.org/10.1016/j. landurbplan.2010.05.002

Burkhard, B., F. Kroll, F. Müller, and W. Windhorst. 2009. Landscapes' capacities to provide ecosystem services - a concept for land-cover based assessments. Landscape Online 15:1-22. http://dx.doi.org/10.3097/LO.200915

Buzai, G. D., and C. A. Baxendale. 2006. Análisis socio-espacial con sistemas de información geográfica. Lugar Editorial, Gepama, Buenos Aires, Argentina.

Cacciapaglia, M. A., L. Yung, and M. E. Patterson. 2012. Place mapping and the role of spatial scale in understanding landowner views of fire and fuels management. Society \& Natural Resources 25:453-467. http://dx.doi.org/10.1080/08941920.2011.580418

CATIE-RIABM. 2012. Estándar para el monitoreo y evaluación de Bosques Modelo. Propuesta para orientas la gestión de iniciativas de la red iberoamericana de Bosques Modelo. CATIE, Turrialba, Costa Rica. [online] URL: http://www.bosquesmodelo.net/wpcontent/uploads/2014/08/CATIE-RIABM-2012.-Estandar-par-elmonitoreo-y-evaluaci $\% \mathrm{C} 3 \% \mathrm{~B} 3 \mathrm{n}$-de-los-Bosques-Modelo..pdf

Chan, K. M. A., J. Goldstein, T. Satterfield, N. Hannahs, K. Kikiloi, R. Naidoo, N. Vadeboncoeur, and U. Woodside. 2011. Cultural services and non-use values. Pages 206-228 in P. Kareiva, H. Tallis, T. H. Ricketts, G. C. Daily, and S. Polasky, editors. Natural capital: theory and practice of mapping ecosystem services. Oxford University Press, Oxford, UK. http://dx.doi.org/10.1093/ acprof:oso/9780199588992.003.0012

Chan, K. M. A., T. Satterfield, and J. Goldstein. 2012. Rethinking ecosystem services to better address and navigate cultural values. Ecological Economics 74:8-18. http://dx.doi.org/10.1016/j. ecolecon.2011.11.011

Christie, M., I. Fazey, R. Cooper, T. Hyde, and J. O. Kenter. 2012. An evaluation of monetary and non-monetary techniques for assessing the importance of biodiversity and ecosystem services to people in countries with developing economies. Ecological Economics 83:67-78. http://dx.doi.org/10.1016/j.ecolecon.2012.08.012

Clement, J. M., and A. S. Cheng. 2006. Public values and preferences regarding forest uses and management on the Pike and San Isabel National Forests, Colorado. Survey Results. Department of Forest, Rangeland and Watershed Stewardship, Colorado State University, Fort Collins, Colorado, USA.

Corporación Nacional Forestal (CONAF). 2007. Documento base para la incorporación del territorio andino de la región de Los Lagos a la red mundial de Reservas de Biosfera. Programa MAB - UNESCO, Paris, France.

Corporación Nacional Forestal (CONAF). 2014. Monitoreo de Cambios, Corrección Cartográfica y Actualización del Catastro de los Recursos Vegetacionales Nativos de la región de Los Ríos. CONAF, Santiago, Chile.

Darvill, R., and Z. Lindo. 2015. Quantifying and mapping ecosystem service use across stakeholder groups: implications for conservation with priorities for cultural values. Ecosystem Services 13:153-161. http://doi.org/10.1016/j.ecoser.2014.10.004 http:// dx.doi.org/10.1016/j.ecoser.2014.10.004

Davies, K. K., K. T. Fisher, M. E. Dickson, S. F. Thrush, and R. Le Heron. 2015. Improving ecosystem service frameworks to address wicked problems. Ecology and Society 20(2):37. http://dx. doi.org/10.5751/es-07581-200237 
DeWalt, K. M., and B. R. DeWalt. 2010. Participant observation: a guide for fieldworkers. Rowman Altamira, Walnut Creek, California, USA.

Fagerholm, N., N. Käyhkö, F. Ndumbaro, and M. Khamis. 2012. Community stakeholders' knowledge in landscape assessmentsmapping indicators for landscape services. Ecological Indicators 18:421-433. http://dx.doi.org/10.1016/j.ecolind.2011.12.004

Felipe-Lucía, M. R., F. A. Comín, and E. M. Bennett. 2014. Interactions among ecosystem services across land uses in a floodplain agroecosystem. Ecology and Society 19(1):20. http:// doi.org/10.5751/ES-06249-190120

Freeman, R. E. 1984. Stakeholder management: framework and philosophy. Pitman, Mansfield, Massachusetts, USA.

Gould, R. K., S. C. Klain, N. M. Ardoin, T. Satterfield, U. Woodside, N. Hannahs, G. C. Daily, and K. M. A. Chan. 2015. A protocol for eliciting nonmaterial values through a cultural ecosystem services frame. Conservation Biology 29(2):575-586. http://dx.doi.org/10.1111/cobi.12407

Hall, T. E., J. O. Farnum, T. C. Slider, and K. Ludlow. 2009. New approaches to forest planning: inventorying and mapping place values in the Pacific Northwest Region. Research Note PNWRN-562. U.S. Forest Service, Portland, Oregon, USA. http://dx. doi.org/10.2737/pnw-rn-562

Hatton-MacDonald, D., R. Bark, A. MacRae, T. Kalivas, A. Grandgirard, and S. Strathearn. 2013. An interview methodology for exploring the values that community leaders assign to multiple-use landscapes. Ecology and Society 18(1):29. http://doi. org/10.5751/ES-05191-180129 http://dx.doi.org/10.5751/es-05191-180129

Hauck, J., C. Görg, R. Varjopuro, O. Ratamäki, and K. Jax. 2013. Benefits and limitations of the ecosystem services concept in environmental policy and decision making: some stakeholder perspectives. Environmental Science \& Policy 25:13-21. http://doi. org/10.1016/j.envsci.2012.08.001 http://dx.doi.org/10.1016/j. envsci.2012.08.001

Instituto Nacional de Estadísticas (INE). 2002. XVII Censo Nacional de Población y VI de Vivienda 2002. INE, Santiago, Chile.

Ives, C. D., and D. Kendal. 2014. The role of social values in the management of ecological systems. Journal of Environmental Management 144:67-72. http://dx.doi.org/10.1016/j.jenvman.2014.05.013

Kellert, S. R. 1995. The biological basis for human values of nature. Pages 42-71 in S. R. Kellert and E. O. Wilson, editors. The biophilia hypothesis. Island Press, Washington, D.C., USA.

Kenter, J. O., L. O’Brien, N. Hockley, N. Ravenscroft, I. Fazey, K. N. Irvine, M. S Reed, M. Christie, E. Brady, R. Bryce, A. Church, N. Cooper, A. Davies, A. Evely, M. Everard, R. Fish, J. A. Fisher, N. Jobstvogt, C. Molloy, J. Orchard-Webb, S. Ranger, M. Ryan, V. Watson, and S. Williams. 2015. What are shared and social values of ecosystems? Ecological Economics 111:86-99. http://dx.doi.org/10.1016/j.ecolecon.2015.01.006

Kenter, J. O., M. S. Reed, K. N. Irvine, E. O'Brien, E. Brady, R. Bryce, M. Christie, A. Church, N. Cooper, A. Davies, N. Hockley, I. Fazey, N. Jobstvogt, C. Molloy, J. Orchard-Webb, N. Ravenscroft, M. Ryan, and V. Watson. 2014. UK National
Ecosystem Assessment follow-on: work package report 6: shared, plural and cultural values of ecosystems. UNEP-WCMC, Cambridge, UK.

Klain, S. C., and K. M. A. Chan. 2012. Navigating coastal values: participatory mapping of ecosystem services for spatial planning. Ecological Economics 82:104-113. http://doi.org/10.1016/j. ecolecon.2012.07.008 http://dx.doi.org/10.1016/j.ecolecon.2012.07.008

Kull, C. A., X. Arnauld de Sartre, and M. Castro-Larrañaga. 2015. The political ecology of ecosystem services. Geoforum 61:122-134. http://doi.org/10.1016/j.geoforum.2015.03.004 http:// dx.doi.org/10.1016/j.geoforum.2015.03.004

Laterra, P., M. E. Orúe, and G. C. Booman. 2012. Spatial complexity and ecosystem services in rural landscapes. Agriculture, Ecosystems and Environment 154:56-67. http://doi. org/10.1016/j.agee.2011.05.013 http://dx.doi.org/10.1016/j. agee.2011.05.013

López-Santiago, C. A., E. Oteros-Rozas, B. Martín-López, T. Plieninger, E. G. Martín, and J. A. González. 2014. Using visual stimuli to explore the social perceptions of ecosystem services in cultural landscapes: the case of transhumance in Mediterranean Spain. Ecology and Society 19(2):27. http://dx.doi.org/10.5751/ es-06401-190227

Maass, J., P. Balvanera, A. Castillo, G. C. Daily, H. A. Mooney, P. Ehrlich, M. Quesada, A. Miranda, V. J. Jaramillo, F. GarcíaOliva, A. Martínez-Yrizar, H. Cotler, J. López-Blanco, A. PérezJiménez, A. Búrquez, C. Tinoco, G. Ceballos, L. Barraza, R. Ayala, and J. Sarukhán. 2005. Ecosystem services of tropical dry forests: insights from long-term ecological and social research on the Pacific Coast of Mexico. Ecology and Society 10(1):17.

Millennium Ecosystem Assessment (MEA). 2005. Ecosystems and human well-being: synthesis. Island Press, Washington, D.C., USA. [online] URL: http://www.millenniumassessment.org/ documents/document.356.aspx.pdf

Ministerio de Economía, Fomento y Reconstrucción de Chile. 2005. Política Nacional de Turismo. Ministerio de Economía, Fomento y Reconstrucción de Chile, Santiago, Chile

Ministerio de Economía, Fomento y Turismo de Chile. 2012. Decreto 172. Procedimientos para la declaración de zonas de interés turístico. Ministerio de Economía, Fomento y Reconstrucción de Chile, Santiago, Chile

Mitchell, A. 2005. The ESRI guide to GIS analysis. Volume 2: spatial measurements and statistics. ESRI, Redlands, California, USA.

Municipalidad de Panguipulli. 2008. Plan de Desarrollo Comunal Panguipulli 2008-2012. Panguipulli, Chile.

Municipalidad de Panguipulli. 2012. Plan de Ordenamiento Territorial ZOIT. Panguipulli, Chile.

Nahuelhual, L., P. Laterra, S. Villarino, M. Mastrángelo, A. Carmona, A. Jaramillo, P. Barral, and N. Burgos. 2015. Mapping of ecosystem services: missing links between purposes and procedures. Ecosystem Services 13:162-172. http://doi.org/10.1016/ j.ecoser.2015.03.005 http://dx.doi.org/10.1016/j.ecoser.2015.03.005

Nelson, E., G. Mendoza, J. Regetz, S. Polasky, H. Tallis, D. R. Cameron, K. M. A. Chan, G. C. Daily, J. Goldstein, P. M. Kareiva, 
E. Lonsdorf, R. Naidoo, T. H. Ricketts, and M. R. Shaw. 2009. Modeling multiple ecosystem services, biodiversity conservation, commodity production, and tradeoffs at landscape scales. Frontiers in Ecology and the Environment 7:4-11 http://dx.doi. $\underline{\mathrm{org} / 10.1890 / 080023}$

Palomo, I., B. Martín-López, P. Zorrilla-Miras, D. García del Amo, and C. Montes. 2014. Deliberative mapping of ecosystem services within and around Doñana National Park (SW Spain) in relation to land use change. Regional Environmental Change 14:237-251. http://dx.doi.org/10.1007/s10113-013-0488-5

Pino-Piderit, A., P. Cardyn, Grupo de trabajo Panguipulli (GTP). 2014. La Reserva de la Biosfera de los Bosques Templados Lluviosos de los Andes Australes y las singularidades territoriales de la comuna de Panguipulli. Pages 190-206 in A. Moreira-Muñoz and A. Borsdorf, editors. Reservas de la biósfera de Chile: Laboratorios para la sustentabilidad. Austrian Academy of Science, Innsbruck, Austria, and Pontificia Universidad de Chile, Santiago de Chile, Chile.

Plieninger, T., S. Dijks, E. Oteros-Rozas, and C. Bieling. 2013. Assessing, mapping, and quantifying cultural ecosystem services at community level. Land use Policy 33:118-129. http://dx.doi. org/10.1016/j.landusepol.2012.12.013

Raymond, C. M., B. A. Bryan, D. Hatton-MacDonald, A. Cast, S. Strathearn, A. Grandgirard, and T. Kalivas. 2009. Mapping community values for natural capital and ecosystem services. Ecological Economics 68:1301-1315. http://dx.doi.org/10.1016/j. ecolecon.2008.12.006

Raymond, C. M., J. O. Kenter, T. Plieninger, N. J. Turner, and K. A. Alexander. 2014. Comparing instrumental and deliberative paradigms underpinning the assessment of social values for cultural ecosystem services. Ecological Economics 107:145-156. http://dx.doi.org/10.1016/j.ecolecon.2014.07.033

Reed, M. S., A. Graves, N. Dandy, H. Posthumus, K. Hubacek, J. Morris, C. Prell, C. H. Quinn, and L. C. Stringer. 2009. Who's in and why? A typology of stakeholder analysis methods for natural resource management. Journal of Environmental Management 90:1933-1949. http://doi.org/10.1016/j.

jenvman.2009.01.001 http://dx.doi.org/10.1016/j.jenvman.2009.01.001

Schnegg, M., R. Rieprich, and M. Pröpper. 2014. Culture, nature, and the valuation of ecosystem services in Northern Namibia. Ecology and Society 19(4):26. http://dx.doi.org/10.5751/ es-06896-190426

Scholte, S. S. K., A. J. A. van Teeffelen, and P. H. Verburg. 2015. Integrating socio-cultural perspectives into ecosystem service valuation: a review of concepts and methods. Ecological Economics 114:67-78. http://doi.org/10.1016/j.ecolecon.2015.03.007

Sherrouse, B. C., J. M. Clement, and D. J. Semmens. 2011. A GIS application for assessing, mapping, and quantifying the social values of ecosystem services. Applied Geography 31:748-760. http://doi.org/10.1016/j.apgeog.2010.08.002

Sherrouse, B. C., D. J. Semmens, and J. M. Clement. 2014. An application of social values for ecosystem services (SolVES) to three national forests in Colorado and Wyoming. Ecological Indicators 36:68-79. http://dx.doi.org/10.1016/j.ecolind.2013.07.008
Spangenberg, J. H., C. von Haaren, and J. Settele. 2014. The ecosystem service cascade: further developing the metaphor. Integrating societal processes to accommodate social processes and planning, and the case of bioenergy. Ecological Economics 104:22-32. http://dx.doi.org/10.1016/j.ecolecon.2014.04.025

Tapia, C. 2014. Identificación participativa de servicios ecosistémicos en la comuna de Panguipulli. Tesis de Magíster. Valdivia, Chile. Facultad de Ciencias Agrarias y Facultad de Filosofía y Humanidades, Universidad Austral de Chile.

Tsirogianni, S., and G. Gaskell. 2011. The role of plurality and context in social values. Journal for the Theory of Social Behaviour 41:441-465. http://dx.doi.org/10.1111/j.1468-5914.2011.00470.x

Van Riper, C. J., G. T. Kyle, S. G. Sutton, M. Barnes, and B. C. Sherrouse. 2012. Mapping outdoor recreationists' perceived social values for ecosystem services at Hinchinbrook Island National Park, Australia. Applied Geography 35:164-173. http:// dx.doi.org/10.1016/j.apgeog.2012.06.008

Villamagna, A. M., P. L. Angermeier, and E. M. Bennett. 2013. Capacity, pressure, demand, and flow: a conceptual framework for analyzing ecosystem service provision and delivery. Ecological Complexity 15:114-121. http://dx.doi.org/10.1016/j.ecocom.2013.07.004

Villamor, G. B., I. Palomo, C. A. L. Santiago, E. Oteros-Rozas, and J. Hill. 2014. Assessing stakeholders' perceptions and values towards social-ecological systems using participatory methods. Ecological Processes 3:1-12. http://doi.org/10.1186/s13717-014-0022-9

Wackernagel, M., and W. E. Rees. 1997. Perceptual and structural barriers to investing in natural capital: economics from an ecological footprint perspective. Ecological economics 20:3-24. http://dx.doi.org/10.1016/S0921-8009(96)00077-8

Wilson, E. O. 1984. Biophilia. Harvard University Press, Cambridge, Massachusetts, USA.

Wong, C. P., B. Jiang, A. P. Kinzig, K. N. Lee, and Z. Ouyang. 2015. Linking ecosystem characteristics to final ecosystem services for public policy. Ecology Letters 18:108-118. http://doi. org/10.1111/ele.12389 